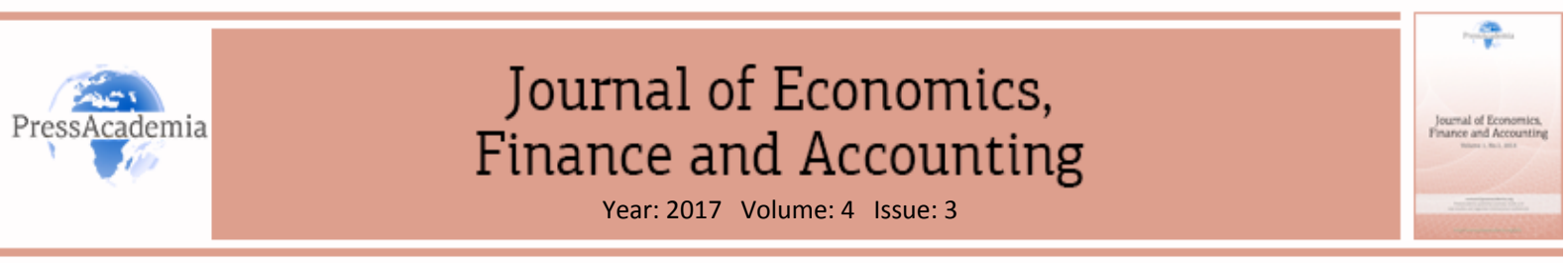

\title{
THE RELATIONSHIP BETWEEN INNOVATION AND FIRM PERFORMANCE: A SURVEY ON AUDITING FIRMS IN TURKEY ${ }^{1}$
}

\author{
DOI: 10.17261/Pressacademia.2017.691
}

JEFA- V.4-ISS.3-2017(3)-p.237-244

\section{Eymen Gurel}

Muğla Sıtkı Koçman Universty, i.i.i.B.F., 48800, Muğla, Turkey. eymengurel@mu.edu.tr

\section{To cite this document}

Gurel, E., (2017). The relationship between innovation and firm performance: a survey on auditing firms in Turkey. Journal of Economics, Finance and Accounting (JEFA), V.4, Iss.3, p.237-244.

Permemant link to this document: http://doi.org/10.17261/Pressacademia.2017.691

Copyright: Published by PressAcademia and limited licenced re-use rights only.

\begin{abstract}
Purpose - The purpose of this study is to examine whether there is a statistically significant relationship between innovation and firm performance of auditing firms.

Methodology -The study was carried out with 66 accountants working in the auditing firms and assigned with audit mandate by The Public Oversight, Accounting \& Auditing Standards Authority. The scale developed by Calantone and et al. (2002) and consisting of 6 items was used in the study to measure innovation. The firm performance scale developed by Khandwalla (1977), consisting of 5 items, was used to measure performance. Proposed relations were tested through factor analysis, correlation analysis and regression analyses.

Findings- As a result of the research, it has been detected a significant and positive relationship between innovation and firm performance in the auditing firms.

Conclusion- It has become clear that auditing firms have focused on innovation, especially in service and process inovation, and that their solution offers have been welcomed by customers and firms' performance. Accordingly, service quality will increase thanks to the ersistent innovation orientations of the auditing firms and their proactive measures against the first time encountered business tricks.
\end{abstract}

Keywords: Innovation, firm performance, audit, accounting, auditing firms.

JEL Codes: M41, M42, M48

\section{INTRODUCTION}

Before explaining innovation and firm performance over audit companies whose history do not go back a long way in Turkey, it is important to describe audit. "An audit is a systematic and independent examination of economic activities and phenomenon according to the pre-determined criteria and also attempts to gather and evaluate evidence as required by law" (Güredin, 11:2010).

As understood from the definition, auditing is a means of dealing with the economic data of the firms and gives information to the stakeholders about the reliability and validity of these data. Particularly, the accounting scandals (Worldcom, Enron and et al.) have once again revealed the importance of auditing for all beneficiaries. Although the auditors seem to reach worksheets easily with the rise of technological opportunities, it unfortunately brings about serious deception opportunities (E-Bill, E-Banking, matrix code or 2D barcode, Photoshop and etc.). That's an obligation obligatory for auditing companies to follow and create innovations in their auditing process. This requirement plays an important key role to reduce the auditing risk and also enhances firm performance. Even if auditing companies have audited the same firm many times, they have to re-plan and re-design each auditing process. An employee who has just started to work in that conjectural developments, or the firm's effort to meet the target can cause the auditing firm to encounter unwanted consequences which it has not before. Thus, it is important for the auditing firm to benefit from such concepts like process innovation. Undoubtedly, the performance of the firms that do not renew their processes regularly will be negatively affected. While the auditors

\footnotetext{
${ }^{1}$ This paper presented at the 13th International Strategic Management Conference, Montenegro,2017.
} 
investigate whether financial statements reflect the reality or not, they control the environment inside and outside the firm vigorously and they try to minimize the risk of not being able to detect it. If the auditing risk is low, the firm will meet the needs of the customer quickly and increase the quality of the services they will offer. All of them will have a positive effect on the partners of the auditing company and improve the performance of the company.

In the theoretical part of the study, the development of the auditing firms in Turkey is explained with the concept of innovation. Then, the conceptual framework is drawn by examining the relationship between firm performance and innovation. In the empirical part of the study, the relationship between the innovation level of audit firms in Turkey and firm performance is analyzed. The purpose of the research is to analyze whether there is a relationship between the level of innovation of the auditing firms and the performance of the firm, and if so, to reveal the direction and severity of this relationship. In the literature, it has been found that limited number of studies analyze the relationship between innovation and firm performance of the auditing firms. For this reason, it is thought that this study will fill the gap in the scholarly literature.

\section{DEVELOPMENT OF AUDITING COMPANIES IN TURKEY}

The foreign-invested companies felt the need to have their investments audited and partnership rights checked in Turkey in the 1960s and this brought along the foundation of domestic audit firms in the 1970s (Bezirci and Karasioğlu, 2011:576). The foundation of Istanbul Stock Exchange in 1985 and the firms' going public by selling their shares increased the need for independent auditing. According to the official data on the web page of the Capital Markets Board, there have been 100 independent auditing companies in capital market entitled to independent auditing in Turkey since 2017 (Retrieved from http://www.spk.gov.tr/apps/msd/iletisim.aspx, 08.04.2017).

However, the main progress has been experienced when The Public Oversight, Accounting \& Auditing Standards Authority(POA) was established by the Statutory Decree No. 660 and on 2.11.2011. With the effect of new Turkish commercial law, POA has aimed to expand auditing in Turkey and it has made it necessary to audit not only publicly traded shares (or open joint stock company) but also non-public companies within the framework of different criteria. Within this context, "Independent Audit Regulation" prepared by POA was published in the official journal numbered 28509 and 26.12.2012 dated.

With the regulation's date of issue, those with a 15 year professional experience and who were entitled to become Swornin Certified Public Accountants-SCPA and Certified Public Accountants-CPA should apply with their licences until 31.12.2014. If they fulfil the requirements other than the examination required in Article 14 of the Regulation and successfully complete the transition period training programs stipulated by the Authority regarding the exam topics specified in the Article 16, they will be entitled to obtain an independent auditor's licence.

According to the statistics published by POA, the distribution of independent auditing companies and the number of auditors are summarized in Table 1.

Table 1: The Distribution of Independent Audit Companies and The List of Auditors Registered by POA

\begin{tabular}{|l|c|c|c|c|c|c|c|c|}
\hline & \multicolumn{4}{|c|}{ THE DISTRIBUTION OF INDEPENDENT AUDIT COMPANIES IN } & \multicolumn{3}{c|}{$\begin{array}{c}\text { THE NUMBER OF AUDITORS IN } \\
\text { REGISTERED BY POA }\end{array}$} \\
\hline Year & İstanbul & Ankara & İzmir & Others & Total & CPA & SCPA & TOTAL \\
\hline $\mathbf{2 0 1 3}$ & 22 & 6 & 3 & 3 & $\mathbf{3 4}$ & 3.802 & 1.251 & $\mathbf{5 . 0 5 3}$ \\
\hline $\mathbf{2 0 1 4}$ & 63 & 25 & 7 & 16 & $\mathbf{1 1 1}$ & 4.244 & 993 & $\mathbf{5 . 2 3 7}$ \\
\hline $\mathbf{2 0 1 5}$ & 26 & 9 & 2 & 14 & $\mathbf{5 1}$ & 2.652 & 338 & $\mathbf{2 . 9 9 0}$ \\
\hline $\mathbf{2 0 1 6}$ & 21 & 3 & 3 & 12 & $\mathbf{3 9}$ & 1.191 & 72 & $\mathbf{1 . 2 6 3}$ \\
\hline Total & 132 & 43 & 15 & 45 & $\mathbf{2 3 5}$ & 11.889 & 2.654 & $\mathbf{1 4 . 5 4 3}$ \\
\hline
\end{tabular}

Retrieved from http://kgk.gov.tr/DynamicContentDetail/6731/Tablo-1-Bag\%CC\%86\%C4\%B1ms\%C4\%B1z-Denetim-

Kurulus\%CC\%A7lar\%C4\%B1n\%C4\%B1n-I\%CC\%87llere-Go\%CC\%88re-Dag\%CC\%86\%C4\%B1/\%C4\%B1m\%C4\%B1, 08.04.2017) (Retrieved from http://kgk.gov.tr/DynamicContentDetail/6705/Tablo-4-Sicile-Kaydedilen-Denetc\%CC\%A7iler, 08.04.2017)

As presented in the Table 1, there are 235 audit companies operating in Turkey including those authorized by the Capital Markets Board and accredited by POA. Moreover, according to the statistics given by the POA, the distribution of 14,543 accounting professionals entitled to use the supervisory authority was presented on the same table.

14,543 professionals authorized by the POA are required to take part in an auditing company in order to be able to carry out the independent audit together with the audit authority. However, a large part of this number has acquired the document only as an acquired right and does not use the independent audit authority within a company in practice (academic members, non-retired public employees, accounting professionals who have not signed contracts with audit companies, etc.). 


\section{LITERATURE REVIEW}

\subsection{Innovation}

In today's global competitive environment, change is so rapid and the innovation capabilities give firms the advantage of gaining competitive advantage and enhancing their performance. Innovation provides important skills to businesses to become high performance organizations and to recreate the environment (Avcl, 2009:125-126). Innovativeness reflects a firm's tendency to engage in and support new ideas, novelty, experimentation and creative processes that may result in new products, services, or technological processes (Lumpkin and Dess, 1996, as cited in Zehir, Özşahin, 2011:51) According to Damonpour, innovation can be a new product or a service development, redefinition of business, restructuring, new managerial system, a plan or a program (Damonpour, 1991:556). There is no common definition of innovation accepted by the researchers. Innovation is usually defined as the development and / or use of new ideas and behaviours. A new idea might be about a new product, service, market, management structure, process and system. Today, organizations are pushed to make innovations with the pressure of the outer circle. Organizations make innovations to compete, meet customer demands, use scarce resources efficiently, gain different skills, increase service quality and achieve their goals (Damanpour et al., 2009:652). According to Bakar and Ahmad (2010), the ability to innovate with regard to product and business is of critical importance for a firm to evaluate new opportunities and to gain competitive advantage. Innovation is a key factor for creating firm success and sustainable competitive advantage. Beaver (2002) states that innovation is the basic element for the country's economic development and for the industry to gain competitive advantage. According to Sandvik (2003), innovation is one of the most important competitive weapons and often reflects a company's core competence (Rosely and Sidek, 2013:2).

Schumpeter (1934), who firstly defined the concept of innovation, expresses innovation as a driving force that leads development. Schumpeter's definition of innovation consists of five elements: 1 . new products or developing the existing products, 2. using new production processes, 3. new markets, 4. creating new materials or resources, and 5. new forms of industrial organizations (As cited in Hazel-Er, 2013:78). Based on Oslo Manual published by OECD, innovation has been defined as the implementation of a new or significantly improved product (good or service), or a process, a new marketing method, or a new organizational method in business practices, workplace organization or external relations (Oslo Manual, 2005). Innovation is basically innovative ideas that enhance organizational performance. Damanpour and Goplakrishnan (2001) define innovation as the acceptance of any idea or method related to a product, service, system, tool, policy or program that is new to the organization. According to Tutar et al (2007: 196), innovation refers to the transformation of new ideas into economy. In Thompson's opinion (1965), innovation is the generation, acceptance and implementation of new ideas, products, processes and services. And according to Amabile et al. (1996), innovation is the successful implementation of creative ideas in an organization.

Damanpour and Evan (1984) classified innovation as product, process, and managerial innovation (Hassan et al., 2013: 244). Innovation can be carried out with a company's products, services, production, distribution methods, business methods, design and marketing methods. These are called "product innovation", "service innovation", "process innovation", "organizational innovation" and "marketing innovation" respectively (Çiçek and Onat, 2012:47).

\subsection{Innovation and Performance}

Innovation is considered as a crucial key in changing environments to enhance firm performance. Following a strategy based merely on reducing costs and lowering prices would be insufficient to provide more than a limited advantage to businesses in the market (Avcl, 2009: 125). Companies with high levels of innovation are much more successful in responding to customer needs, developing new capabilities and achieving higher profitability. Innovation is critical in improving operational efficiency and service quality (Wang and Wang, 2012: 8901).

Researchers indicate that innovation is a noteworthy important tool in enhancing firm performance through organizational adaptation and change, especially in areas where there is intense competition in dynamic business environments and where customer demands are constantly changing. According to Hitt et al. (1991), it is possible to create strategic competitive advantage only with the development of new technologies by firms. Although innovation is not awarded directly in the market, it is crucial for the organization to make changes in its environment and produce dynamic skills.

Firm performance is defined as the level of performance of the business purpose or task according to the outputs or results obtained at a certain period (Akal, 2003). Performance is the qualitative or quantitative evaluation of all intended efforts and results for the achievement of objectives (Akman and Yılmaz, 2008: 94). The concept of performance can be defined as the ability of the organization to cope with all systematic processes related to achieving organizational goals, or the ability of an organization to effectively perform organizational functions and to maintain organizational alignment. Khandawalla (1977:572) defines organizational performance as "the achievement of the organization as a whole". 
The performance is related to the task and the person, and it is the level of fulfillment of the task in order to meet the predetermined measures as required by the task (Biçkes and Özdevecioğlu, 2016:12). Organizations aim to respond to environmental demands, maintain their activities efficiently and improve their performances via innovation. Researchers emphasize that innovation positively affects firm performance although innovation is risky and success is not guaranteed. Jansen et al. (2006) suggest that innovation in dynamic and competitive environments improve firm performance. Innovation activities increase the organizations' awareness of recent developments and their chances of creating competitive advantage by internalizing new information (Damanpour et al., 2009: 653-655).

Firm performance is the degree to which internal and external objectives are achieved according to the results achieved by a firm. From a multi-dimensional perspective, performance includes all the concepts of growth, sustainability, success and competitiveness. There are different methods to measure firm performance. These methods can be classified into two categories: financial and non-financial methods. Firm performance can be measured with indicators like profitability, efficiency, satisfaction of share holders, and market share. In addition to this, such indicators like net profit after tax, return on investment, and return on assets are frequently preferred in measuring firm performance. On the other hand, it is frequently stated that financial factors are insufficient to measure the firm performance. Financial measurements are limited measurements by their focus, so these indicators are often insufficient to reflect actual firm performance (Erdem et al, 2011:85). Non-financial indicators such as product / service quality, customer satisfaction and new product / service development are also methods used to measure firm performance.

The studies carried out in literature revealed that there was a positive relationship between innovation and firm performance. The research study carried out by Küçük and Kocaman (2014) on tourism-certified enterprises in the province of Agri revealed a significant relationship between innovation activities and customer orientation and firm performance. Atalay et al. found (2013) that product and process innovation had a positive and significant effect on firm performance (Atalay et al., 2013:227). Roberts (1999) revealed that there was a positive relation between product innovation and sustainable profitability. Han et al. (1998) determined that managerial and technical innovation had a positive effect on firm performance (Atalay et al. 2013:229). In a study carried out by Tuan et al.(2016:423), it was found that process innovation, marketing innovation, and managerial innovation affected firm performance positively. Similarly, Ul Hassan et al. (2013:243) carried out a study and the findings of this study reveal that types of innovation had a positive effect on firm performance. In a study carried out by Thornhill (2006:687), it was determined that innovative firms have increased their profits independently of the sector they are in. Calantone et al . (2002) in their study ascertained that there was a positive relationship between firm innovation and firm performance. Özşahin et al. (2005: 152) carried out a study on 52 manufacturing businesses in Marmara region and they found that innovation ability affected the firm performance positively. Erdil and Kitapçı (2007: 242) conducted a study on 96 businesses operating in manufacturing sector in Marmara region and determined that the firm innovation affected the firm performance positively and significantly. The research study conducted by Zehir and Özşahin (2006: 149) on 73 companies operating in the manufacturing sector and listed on the Top 500 Businesses in Turkey revealed that there is a positive and a significant relationship between the firm performance and firm innovation.

\section{DATA AND METHODOLOGY}

The purpose of this study is to examine whether there is a statistically significant relationship between innovation and firm performance of auditing firms. In this study, firm performance was considered as dependent and innovation was taken as independent variable. A hypothesis was developed to reveal whether there was a significant difference between the variables or not and whether these hypotheses were supported or not. The subject draws attention because there are only a few studies which have examined the relationship between the innovation and firm performances of auditing firms.

$\mathrm{H} 1$ : There is a positive and statistically significant relationship between the innovation and firm performances of auditing firms.

\subsection{Sample and Data Collection}

With the permission of the POA, the sampling of the research consists of CPA (independent accountant financial consultants) and SCPA (certified accountants), who are participants of "Transitional Audit Training" held in Istanbul, Izmir, Bursa and Muğla with at least 15 years of professional experience. A pilot study was carried out with 10 professional accountants who participated in these trainings before starting the research and then the questionnaire was finalized and administered. Out of the 140 questionnaires distributed to professional accountants, 108 were returned. However, because it was identified that only 66 of these questionnaires were used within the control of an auditing firm, the remaining questionnaires were not included in the sampling. 
Table 2: Demographic Characteristics of Accountants Included in the Sampling

\begin{tabular}{|l|c|c|l|c|c|}
\hline $\begin{array}{l}\text { Demographic } \\
\text { characteristics }\end{array}$ & Number & $\%$ & Demographic characteristics & Number & $\%$ \\
\hline GENDER & & & MARITAL STATUS & & \\
\hline Female & 17 & 26 & Married & 42 & 64 \\
\hline Male & 49 & 74 & Single & 16 & 24 \\
\hline AGE & & & Divorced & 8 & 12 \\
\hline $30-35$ & 5 & 8 & WORK EXPERIENCE & & \\
\hline $36-40$ & 28 & 42 & Less than a Year & 18 & 27 \\
\hline $41-45$ & 21 & 32 & Between 1 and 10 years & 41 & 62 \\
\hline $45-50$ & 7 & 11 & More than 10 years & 7 & 11 \\
\hline $50+$ & 5 & 7 & TITLE & & \\
\hline LEVEL OF EDUCATION & & & CPA & 57 & 86 \\
\hline Undergraduate & 61 & 92 & SCPA & & 14 \\
\hline Post Graduate & 5 & 8 & & & \\
\hline
\end{tabular}

\subsection{Analysis}

The scale developed by Calantone and et al. (2002) and consisting of 6 items was used in the study to measure innovation. The responses were obtained via 5 item Likert Scale in this study. The innovation scale's Cronbach's alpha coefficient was found to be 0,889 in the research study. This scale was used by Özşahin et.al. (2005) , Erdil and Kitapçı (2007), Erdem et.al (2013) in Turkey.

The firm performance scale developed by Khandwalla (1977) was used to measure performance. This scale consists of total 5 statements and the responses were obtained via 5 item Likert Scale ( $1=1$ strongly disagree, $5=$ I strongly agree). The scale was used by Zehir and Özşahin (2006) in their study called "The Relationship between Managerial and Environmental Factors Affecting Strategic Decision Making Speed and Firm Performance: A Case Study in Manufacturing Sector". As a result of reliability analyses, Cronbach's alpha reliability coefficient of performance items was determined to be 0,908 . In this study, Cronbach's alpha coefficient of both models was found to be 0,871 .

\section{FINDINGS AND DISCUSSIONS}

\subsection{Factor Analysis}

In the study, 11 questions prepared by using 5 item Likert Scale $(5$ questions for firm performance and 6 questions for innovation) were used to measure the variables. As a result of the factor analysis, the questions were not removed from the scale because they did not reduce the reliability of the scale by dropping to the other factors or they did not show distribution.11 questions were on 2 factors. Using the SPSS 20.00 statistical package program, innovation as an independent variable was subjected to factor analysis together with the dependent variable firm performance. The scales used to measure the variables subjected to factor analysis in the study are shown in the following tables together with the factor loads.

Table 3: Factor Analysis Results Between Firm Performance and Innovation

\begin{tabular}{|l|c|c|}
\hline & Firm Performance & Innovativeness \\
\hline 1. FIRM PERFORMANCE 1 & 0,910 & \\
\hline 2. FIRM PERFORMANCE 2 & 0,858 & \\
\hline 3. FIRM PERFORMANCE 3 & 0.837 & \\
\hline 4. FIRM PERFORMANCE 4 & 0.707 & \\
\hline 5. FIRM PERFORMANCE 5 & 0.629 & 0.878 \\
\hline 6. INOVATION 1 & & 0.804 \\
\hline 7. INOVATION 2 & & 0.696 \\
\hline 8. INOVATION 3 & & 0.681 \\
\hline 9. INOVATION 4 & & 0.675 \\
\hline 10. INOVATION 5 & & 0.513 \\
\hline 11. INOVATION 6 & \\
\hline Stated TotaI variance \%71,454 & \\
\hline
\end{tabular}




\subsection{Correlation Coefficients of Variables}

Pearson correlation coefficients belonging to the variables were presented in Table 4. A significant relationship between the variables at the level of $p<0.01$ draws attention. Regression analysis was used to determine the direction of these relationships and to test hypotheses.

Table 4: Correlation Coefficeints of Variables

\begin{tabular}{|l|l|c|c|}
\hline \multicolumn{2}{|c|}{} & INNOVATION & FIRM PERFORMANCE \\
\hline \multirow{3}{*}{ INNOVATION } & Pearson Correlation & 1 &, $772^{* *}$ \\
\cline { 2 - 4 } & Sig. (2-tailed) & &, 000 \\
\cline { 2 - 4 } & $\mathrm{N}$ & 66 & 66 \\
\hline \multirow{3}{*}{$\begin{array}{l}\text { FIRM } \\
\text { PERFORMANCE }\end{array}$} & Pearson Correlation &, $772^{* *}$ & 1 \\
\cline { 2 - 4 } & Sig. (2-tailed) &, 000 & 66 \\
\cline { 2 - 4 } & $\mathrm{N}$ & 66 & \\
\hline
\end{tabular}

**. Correlation is significant at the 0.01 level (2-tailed).

\subsection{Regression Analysis Between Innovation and Firm Performance}

The model reveals that innovation represents $59.7 \%$ of the firm's performance and that this is significant at $p<0.01$ in relation to organizational performance. This indicates that innovation has a performance enhancing effect on the firm performance.

The hypothesis of the model was tested by regression analysis. The relationship between firm performance as a dependent variable and innovativeness as an independent variable was tested by regression analysis. According to the analysis (Table 5), the multiple coefficient of determination $R^{2}$ is 0.597 and $59 \%$ of the change in job satisfaction can be explained by the independent variable in the model. One unit increase in innovativeness of companies involved in the research leads to an increase of 0.79 units in firm performance. Accordingly, $\mathrm{H} 1$ hypothesis is accepted.

Table 5: Regression Analysis between Innovation and Firm Performance

\begin{tabular}{llll}
\hline \multicolumn{2}{l}{ Dependent Variable : Firm Performance } & & \\
\hline Independent Variable & Coefficient & t -value & Significant Level \\
\hline Constant &, 782 & 2,364 & .021 \\
Innovativeness &, 799 & 9,730 & .000 \\
$\mathrm{R}^{2}$ & .597 & & \\
Adjusted R & .590 & & .000 \\
F Change and Sig. F Change & 94,666 & & \\
\hline
\end{tabular}

\section{CONCLUSION}

This study examined whether there is a statistically significant relationship between innovation and firm performance. As a result of the research, it has been detected a significant and positive relationship between innovation and firm performance in the auditing firms. Survey conducted on 66 auditor working in auditing firms in Turkey. It can be said that, firms' performance increased in the way that the audit companies attached importance to innovativeness. It has become clear that auditing firms have focused on innovation, especially in service and process inovation, and that their solution offers have been welcomed by customers and firms' performance increased. When the related literature is examined, there are many studies put forth the positive relationship between innovation and firm performance (Atalay et.al. 2013; Calantone, 2002; Özşahin 2005; Zehir and Özşahin 2006; Thornhill 2006 ). Auditing firms are businesses that are able to maintain their authority and their success with high professional care and rigorously in order not to harm their names as long as they perform their work successfully. Reports they have signed show high public benefits and provide a form of public service under the law numbered 3568. An auditor should focus on the following fundamental principles due to his high moral qualities: an investor with limited means is not harmed and public and bank resources should not be wasted. For this reason, auditors should always prioritize innovation in their services they offer and always develop themselves in their processes.

However, there are some limitations of the study. For example, POA only publishes the numbers of auditing firms and professional accountants who are in charge of auditing as statistical data. According to these figures, as of 2016, there are 235 audit firms in Turkey and 14,543 professional accountants in the accounting profession have a certificate of authority. It is not possible that the average number of members of the profession per audit firm is about 62 persons. POA shares 
information of how much of the members of the accounting profession is an audit company partner or actively using the authority and undoubtedly this will have more beneficial results in terms of determining the population and explaining the sampling. Similarly, although there are only a very limited number of auditing firms that have over 75 partners, the number of auditing companies that have partners which do not exceed ten persons is a large majority.

\section{REFERENCES}

Akal, Z., (2003). İşletmelerde Performans Ölçüm ve Denetimi Çok Yönlü Performans Göstergeleri, MPM Yayınları No: 473, Ankara.

Akman, G. and Yilmaz, C., (2008). Innovative Capability, Innovation Strategy and Market Orientation: an Empirical Analysis in Turkish Software Industry. International Journal of Innovation Management, 12(01), 69-111.

Amabile, T. M., Conti, R., Coon, H., Lazenby, J. and Herron, M., (1996). Assessing the Work Environment for Creativity. Academy of Management Journal, 39(5), 1154-1184.

Atalay, M., Anafarta, N. and Sarvan, F. (2013). The Relationship Between Innovation and Firm Performance: An Empirical Evidence from Turkish Automotive Supplier Industry. Procedia-Social and Behavioral Sciences, 75, 226-235.

Avcı, U. (2009). Öğrenme Yönelimliliğin Yenilik Performansı Üzerine Etkisi: Muğla Mermer Sektöründe Bir Inceleme. ZKÜ Sosyal Bilimler Dergisi, 5 (10), 121-138

Bakar, L. J. A. and Ahmad, H. (2010). Assessing the relationship between firm resources and product innovation performance: A resourcebased view. Business Process Management Journal, 16(3), 420-435.

Beaver, G. and Prince, C. (2002). Innovation, entrepreneurship and competitive advantage in the entrepreneurial venture. Journal of Small Business and Enterprise Development, 9(1), 28-37.

Bezirci, M. and Karasioğlu, F., (2011), Türkiye'de Denetimin Tarihsel Gelişimi, Sosyal Ekonomik Araştırmalar Dergisi, 21, pp.571-592.

Biçkes, D. M. and Özdevecioğlu, M. (2016). İşletmelerde Örgütsel Öğrenmenin Finansal Performans Üzerindeki Etkisi Ve İnovasyonun Aracılık Rolü. Akademik Sosyal Araştırmalar Dergisi, 4(25), 8-28.

Calantone, R. J., Cavusgil, S. T. and Zhao, Y. (2002). Learning orientation, firm innovation capability, and firm performance. Industrial marketing management, 31(6), 515-524.

Cheveerug, A. ve Ussahawanitchakit, P. (2008). Learning Orientation, Innovation Capability, and Organizational Performance in Thai Audit Firms: Moderating Effects of Organization Climate and Uncertainty Environment. Review of Business Research.

Çiçek, H. and Onat, O. K. (2013). İnovasyon Odaklı Faaliyetlerin Firma Performansına Etkisinin Veri Zarflama Analizi İle Belirlenmesi; iMKB Üzerine Bir Araştırma. Mehmet Akif Ersoy Üniversitesi Sosyal Bilimler Enstitüsü Dergisi, 4(7), 46-53.

Damanpour, F. (1991). Organizational Innovation: A Meta-Analysis of Effects of Determinants and Moderators. Academy of Management Journal, 34(3), 555-590.

Damanpour, F. and Gopalakrishnan, S. (2001). The Dynamics of the Adoption of Product and Process Innovations in Organizations, Journal of Management Studies, 38(1), 45-65.

Damanpour, F., Walker, R. M. and Avellaneda, C. N. (2009). Combinative effects of innovation types and organizational performance: A longitudinal study of service organizations. Journal of management studies, 46(4), 650-675.

De Jong, J. P., \& Vermeulen, P. A. (2003). Organizing successful new service development: a literature review. Management decision, 41(9), 844-858.

Erdem, B.,Gökdeniz, A. and Met, Ö, (2011). Yenilikçilik ve İşletme Performansı İlişkisi: Antalya'da Etkinlik Gösteren 5 Yıldızlı Otel İşletmeleri Örneği Dokuz Eylül Üniversitesi İktisadi ve İdari Bilimler Fakültesi Dergisi, 26(2),.77-112.

Erdil, O. and Kitapçı, H., (2007). TKY Araçlarının Kullanımı ve Firma Yenilikçiliğinin Yeni Ürün Geliştirme Hızı ve İşletme Performansına Etkisi, Atatürk Üniversitesi İktisadi ve İdari Bilimler Dergisi, 21(1) 233-245.

Güredin, E., (2010). Denetim ve Güvence Hizmetleri. Türkmen Kitabevi, İstanbul.

Han, J. K., Kim N. and Srivastava, R.K. (1998). Market Orientation and Organizational Performance: Is Innovation a Missing Link? Journal of Marketing, 62(4): 30-45.

Hassan, M., U., Shaukat, S., Nawaz, M. S. and Naz, S., (2013). Effects of Innovation Types on Firm Performance: an Empirical Study on Pakistan's Manufacturing Sector. Pakistan Journal of Commerce \& Social Sciences, 7(2).

Hitt, M.A., Hoskisson, R.E., Ireland, R.D. and Harrison, J.S., (1991). Effects of Acquisitions on R\&D Inputs and Outputs. Academy of Management Journal 34(3): 693-706. 
Hoq, Z ve Ha, N. C. (2009). Innovativeness: Its Antecedents and Impact on SME Business Performance. International Journal of Business and Management 4 (11): 100-110.

Jansen, J. J., Van Den Bosch, F. A. and Volberda, H. W., (2006). Exploratory Innovation, Exploitative Innovation, and Performance: Effects of Organizational Antecedents and Environmental Moderators. Management Science, 52(11), 1661-1674.

Küçük, O. and Kocaman, G., (2014). Müşteri Yönlülük, İnovasyon Yönlülük ve İşletme Performans İlişkisi: Bir Uygulama. The Journal of Academic Social Science Studies, 29, 37-52.

OECD (2005). Oslo Manual: Proposed Guidelines for Collecting and Interpreting Tecnological Innovation Data. Paris.

Özşahin, M., Ciğerim, E. and Gök, M. Ş., (2005). Rekabet Edebilirlik Ve Firma Performansi Ilişkisi Üzerine Bir Saha Araştirmasi. İktisadi ve İdari Bilimler Fakültesi Dergisi, 7(1), 143-155.

Per, H., P., (2012). Girişimcilik ve Yenilikçilik Kavramlarinin Iktisadi Düşüncedeki Yeri: Joseph A. Schumpeter, Selçuk Üniversitesi, SBE, Master Thesis.

Roberts, P. W., (1999). Product Innovation, Product-Market Competition and Persistent Profitability in the US Pharmaceutical Industry. Strategic Management Journal, 655-670.

Rosli, M.M. and Sidek S., (2013). The Impact of Innovation on the Performance of Small and Medium Manufacturing Enterprises: Evidence from Malaysia, Journal of Innovation Management in Small \& Medium Enterprise, DOI: 10.5171/2013.885666.

Thompson, V.,A., (1965). Bureaucracy and Innovation Administrative Science Quarterly, 10(1), Special Issue on Professionals in Organizations, 1-20

Thornhill, S., (2006). Knowledge, Innovation and Firm Performance in High-and Low-Technology Regimes. Journal of Business Venturing, 21(5), 687-703.

Tuan, N., Nhan, N., Giang, P. and Ngoc, N., (2016). The Effects of Innovation on Firm Performance of Supporting Industries in Hanoi, Vietnam. Journal of Industrial Engineering and Management, 9(2), 413-431.

Tutar, F., Kocabay, M. and Arıç, H. (2007). Firmaların Yenilik (Inovasyon) Yaratma Sürecinde Serbest Bölgelerin Rolü: Kayseri Serbest Bölgesi Örneği. Selçuk Üniversitesi Karaman ii BF Dergisi, Yerel Ekonomiler Özel Sayısı, 195-203.

Vincent, L. H., Bharadwaj, S. G., \& Challagalla, G. N. (2004). Does innovation mediate firm performance?: a meta-analysis of determinants and consequences of organizational innovation.

Wang, Z. and Wang, N., (2012). Knowledge Sharing, Innovation and Firm Performance. Expert Systems with Applications, 39(10), 88998908.

Zehir, C. and Özşahin, M., (2006). Stratejik Karar Verme Hizini Etkileyen Örgütsel, Çevresel Faktörler Ve Firma Performansi Ilişkisi: Imalat Sektöründe Bir Saha Çalişmasi. Gazi Üniversitesi İktisadi ve İdari Bilimler Fakültesi Dergisi, 9(1), 1-21.

Zehir, C. and Özşahin, M., (2011). Takım yönetimi ve takım etkinliğini belirleyen faktörler: Savunma Sanayinde AR-GE Yapan Takımlar Üzerinde bir Saha Araştırması Doğuş Üniversitesi Dergisi, 9(2), 266-279. 